\title{
Pengolahan Citra Digital untuk Keyboard Virtual Sebagai Antarmuka pada Aplikasi Berbasis Web
}

\author{
Raksaka Indra Alhaqq*1, Agus Harjoko ${ }^{2}$ \\ ${ }^{1}$ Program Studi Elektronika dan Instrumentasi, FMIPA UGM, Yogyakarta \\ ${ }^{2}$ Jurusan Ilmu Komputer dan Elektronika, FMIPA UGM, Yogyakarta \\ e-mail: *11raksakaindra@gmail.com, ${ }^{2}$ aharjoko@ugm.ac.id
}

\begin{abstract}
Abstrak
Sejak pertama kali komputer ditemukan, keyboard selalu menjadi alat utama yang menjadi penghubung interaksi antara manusia dan komputer. Saat ini banyak komputer yang menerapkan teknologi pengolahan citra untuk menjadikannya perantara interaksi antara komputer dan manusia.

Dalam penelitian ini, penulis mencoba untuk menerapkan teknologi pengolahan citra yang digunakan untuk keyboard virtual pada aplikasi web. Digunakan webcam untuk menangkap citra ujung jari telunjuk. Hasil capture citra akan dikirimkan ke server localhost untuk diproses dengan image processing. Untuk mendeteksi ujung jari telunjuk, digunakan metode Haar Cascade Classifier. Proses pendeteksian tersebut menghasilkan koordinat yang akan dikirimkan ke aplikasi web yang selanjutnya dijadikan acuan untuk menentukan posisi tombol pada keyboard virtual. Sehingga keyboard virtual akan menampilan karakter sesuai dengan yang ditunjuk oleh ujung jari telunjuk.

Dari hasil pengujian yang dilakukan, jarak optimal ujung jari telunjuk dengan webcam adalah $20-35 \mathrm{~cm}$. Derajat kemiringan ujung jari telunjuk untuk dapat terdeteksi antara $0^{\circ}-$ $10^{\circ}$. Sistem mampu mengenali ujung jari telunjuk pada ruangan berlatar belakang putih polos dan terdapat sedikit perabot. Waktu respon untuk menampilkan karakter keyboard virtual ratarata 5,156 detik. Sehingga keyboard virtual pada sistem ini belum mampu dijadikan antarmuka pada aplikasi web, dikarenakan masih sulit digunakan dalam mengarahkan ujung jari telunjuk ke tombol karakter yang diinginkan.
\end{abstract}

Kata kunci-aplikasi web, Haar Cascade Classifier, keyboard virtual, pengolahan citra

Since the first computer was founded, keyboard is always been a primary tool for interaction between humans and computers. Today, many computers use image processing technology to make interaction between computers and humans.

The author try to apply image processing technology that implemented to virtual keyboard on web application. Using a webcam to capture the tip of index finger and the results will be sent to the localhost server for processing with image processing. Using Haar Cascade Classifier method to detect the tip of index finger, it will produce coordinates that sent to the web application and it used as a reference for determining button positions on virtual keyboard. Virtual keyboard characters will display after appointed by the tip of index finger.

From testing results, optimal distance from index finger to webcam is $20-35 \mathrm{~cm}$. System can recognize the tip of index finger on white background and room with few furnitures. Average response time for displaying virtual keyboard sentences is 3 minutes and 28.838 seconds. So the virtual keyboard on this system was not able to be used as interface on web application, because it difficult to use in directing the tip of index finger to the character keys.

Keywords - web application, Haar Cascade Classifier, virtual keyboard, image processing 


\section{PENDAHULUAN}

Sejak ertama kali komputer ditemukan, keyboard selalu menjadi alat utama yang menjadi $\mathcal{N}$ penghubung interaksi antara manusia dan komputer. Seiring berkembangnya arus teknologi dan ilmu pengetahuan yang cepat, banyak perangkat komputer sekarang ini yang perlahan meninggalkan bentuk fisik dari keyboard, tetapi tidak meninggalkan fungsi utamanya. Sebut saja perangkat komputer tablet maupun smartphone.

Tidak ketinggalan pula, saat ini sudah banyak perangkat komputer yang menggunakan teknologi pengolahan citra (image processing), khususnya computer vision. Dengan computer vision manusia bisa berinteraksi dengan komputer hanya dengan gerakan-gerakan khusus pada anggota tubuh atau benda yang berada di sekitarnya tanpa memerlukan perangkat tambahan tertentu. Dengan metode ini pula, diharapkan mampu diterapkan pada keyboard virtual untuk berinteraksi dengan perangkat komputer.

Ada berbagai macam yang dapat dijadikan indikator untuk mendekteksi suatu objek dengan komputer. Bisa dengan warna, bentuk, dan anggota tubuh manusia. Pada penelitian yang telah dilakukan sebelumnya, deteksi objek diterapkan pada jari tangan dengan menggunakan Haar Classifier pada library OpenCV, selanjutnya tracking pergerakan jari tangan diterapkan metode Kalman Filter yang berfungsi untuk memprediksi posisi jari pada frame selanjutnya [1].

Terdapat juga penelitian mengenai penggunaan keyboard virtual yang dihubungkan ke berbagai perangkat seperti handphone, PDA, dan PC. Keyboard virtual yang dimakan "VistaKey" ini menggunakan antarmuka tombol keyboard dengan pancaran sinar proyektor dan sebuah webcam sebagai masukannya, sedangkan hasil keluarannya akan ditampilkan di berbagai perangkat bergerak melalui koneksi dengan server [2].

Pada penelitian ini dilakukan pendeteksian objek berupa ujung jari telunjuk tangan yang kemudian dapat diterapkan untuk penggunaan keyboard virtual sebagai antarmuka pada komputer dan aplikasi web. Pada peneltian ini, digunakan sebuah webcam untuk menangkap citra ujung jari telunuk. Kemudian data akan dikirim ke server untuk dilakukan pengolahan citra dan hasilnya akan digunakan untuk penggunaan keyboard virtual pada aplikasi web.

\section{METODE PENELITIAN}

\subsection{Perancangan Sistem Secara Keseluruhan}

Secara umum, sistem yang dibuat pada penelitian ini terdiri dari dua tahapan, yaitu tahap pelatihan pengenalan ujung jari telunjuk dan tahap pengenalan yang bekerja pada aplikasi web. Pada Gambar 1 menunjukkan blok diagram sistem secara keseluruhan, dimana tahap awal adalah melakukan pelatihan pengenalan ujung jari telunjuk pada citra dengan menggunakan metode Haar Cascade Classifier. Hasil dari pelatihan pengenalan ujung jari ini akan diperoleh nilai fitur Haar yang selanjutnya akan disimpan dalam database pengenalan ujung jari telunjuk yang nantinya digunakan sebagai acuan dalam image processing pada sistem aplikasi web.

Pada tahap pengenalan yang bekerja pada aplikasi web, terdapat client dan server yang bekerja dalam satu notebook yang sama. Client merupakan sistem yang menjalankan aplikasi web melalui browser, sedangkan server yang digunakan adalah server localhost.

Langkah awal yang dilakukan adalah melakukan inialisasi webcam oleh browser. Browser yang digunakan pada penelitian ini adalah Google Chrome versi 31 yang di dalamnya terdapat fitur dukungan webcam API (Application Programming Interface). Dengan adanya fitur ini sebuah webcam dapat merekam citra dan menampilkannya langsung melalui browser.

Webcam pada notebook yang digunakan dalam penelitian ini diatur untuk dapat bekerja dengan laju 5 frame per second (fps), yang artinya setiap 1 detik dapat mengambil frame citra objek sebanyak 5 buah. Setiap frame yang berhasil ditangkap oleh webcam selanjutnya akan dikirim satu per satu ke server localhost melalui koneksi WebSockets.

IJEIS Vol. 5, No. 2, October 2015 : $111-122$ 
Frame citra yang telah sampai di server localhost akan diproses satu per satu pada tahap image processing dengan menggunakan database pengenalan ujung jari yang telah dihasilkan pada proses pelatihan pengenalan ujung jari telunjuk. Setelah ujung jari telunjuk terdeteksi, maka akan didapatkan koordinat posisi ujung jari telunjuk tersebut. Langkah selanjutnya, dilakukan penggambaran berbentuk lingkaran berwarna hijau oleh server localhost berdasarkan koordinat posisi tadi.

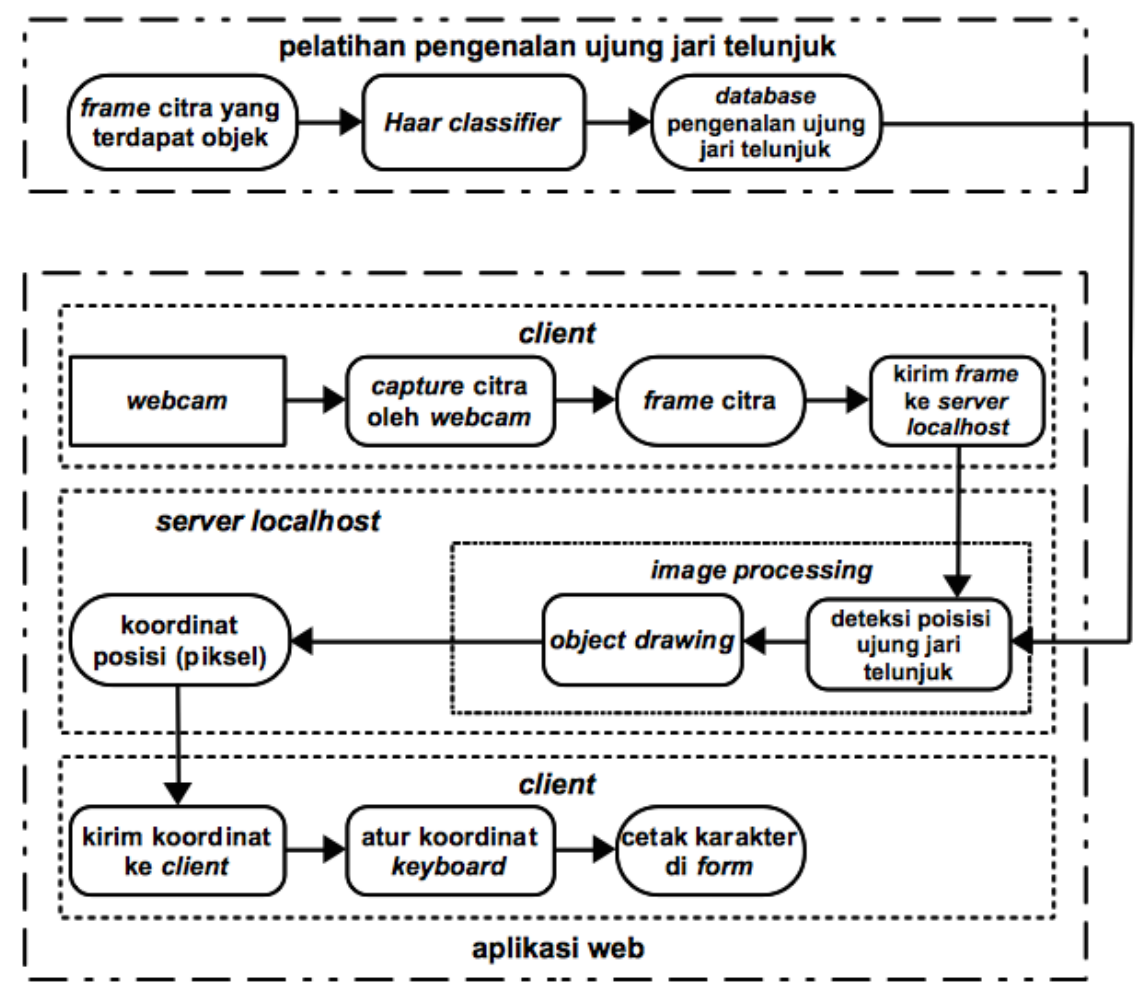

Gambar 1 Blok diagram sistem secara keseluruhan

Setelah dilakukan penggambaran, koordinat posisi yang terdiri dari koordinat piksel horizontal dan vertikal akan dikirimkan ke client. Koordinat piksel posisi ujung jari telunjuk inilah yang akan dijadikan acuan dalam menentukan posisi pada masing-masing tombol pada keyboard virtual. Sehingga pada bagian akhir proses akan menampilkan huruf pada form sesuai dengan koordinat yang ditunjuk oleh ujung jari telunjuk tangan.

\subsection{Perancangan Perangkat Lunak}

\subsubsection{Pelatihan Pengenalan Ujung Jari Telunjuk pada Citra}

Untuk dapat mengenali objek yang diinginkan berupa ujung jari telunjuk tangan kanan maupun tangan kiri pada citra, digunakan metode Haar Cascade Classifier pada 1100 sampel citra yang di dalamnya terdapat objek yang akan dikenali. Untuk melakukan pengenalan ujung jari telunjuk menggunakan Haar Cascade Classifier, terdapat tiga langkah yang harus dilakukan. Langkah pertama, menerapkan Haar template pada citra yang terdapat ujung jari telunjuk. Terdapat tiga jenis Haar template berdasarkan jumlah persegi yang ada di dalamnya, yaitu persegi dengan daerah gelap dan terang seperti yang tampak pada Gambar 2.
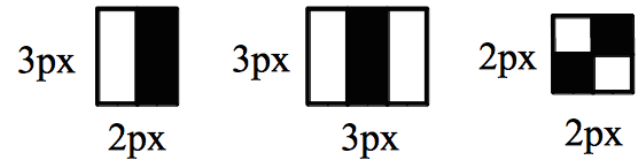

Gambar 2 Haar Template 
Untuk menentukan ribuan Haar template pada sebuah citra secara efisien, dilakukan langkah kedua yaitu, menghitung nilai fitur dengan menggunakan integral image. Integral image adalah sebuah citra yang nilai setiap pikselnya merupakan hasil akumulasi dari nilai piksel atas dan kirinya [3]. Teknik penghitungan ini bisa dilakukan pada Haar template yang diterapkan pada citra seperti yang ditunjukkan oleh Gambar 3. Pada citra yang terdapat ujung jari telunjuk berukuran 20 x 20 piksel akan diterapkan Haar template dengan 2 persegi gelap dan terang berukuran $2 \times 3$ piksel. Pada citra yang akan dilatih, di dalamnya terdapat nilai-nilai piksel, nilai inilah yang akan dirubah ke nilai citra integral dengan menggunakan integral image.

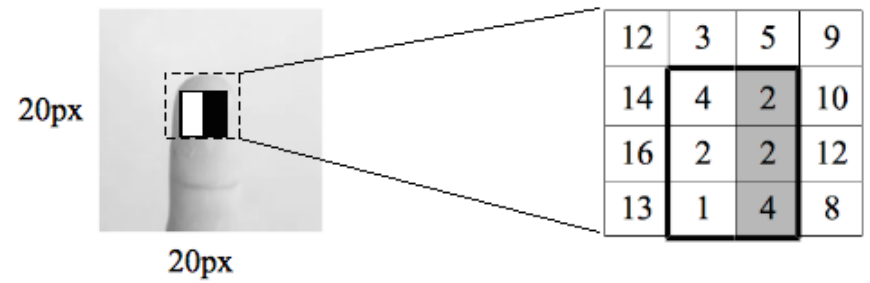

Gambar 3 Penerapan Haar template pada objek ujung jari telunjuk

Seperti yang ditunjukkan oleh Gambar 3, dilakukan pencuplikan nilai piksel dari citra yang dilatih dengan ukuran 4 x 4 piksel. Kemudian diterapkan Haar template dengan ukuran 2 x 3 piksel. Nilai piksel pada daerah yang dilakukan pencuplikan tadi dihitung dengan menggunakan teknik integral image, sehingga menghasilkan nilai citra integral seperti yang ditunjukkan Gambar 4.

\begin{tabular}{|c|c|c|c|}
\hline 12 & $12+3$ & $12+3+5$ & $12+3+5+9$ \\
\hline $12+14$ & $\begin{array}{c}12+3+14 \\
+4\end{array}$ & $\begin{array}{l}12+3+14 \\
+4+5+2\end{array}$ & $\begin{array}{c}12+3+14 \\
+4+5+2 \\
+9+10\end{array}$ \\
\hline $12+14+16$ & $\begin{array}{l}12+3+14 \\
+4+16+2\end{array}$ & $\begin{array}{c}12+3+14 \\
+4+16+2 \\
+5+2+2\end{array}$ & $\begin{array}{c}12+3+14 \\
+4+16+2 \\
+5+2+2 \\
+9+10+12\end{array}$ \\
\hline $\begin{array}{c}12+14+16 \\
+13\end{array}$ & $\begin{array}{c}12+3+14 \\
+4+16+2 \\
+13+1\end{array}$ & $\begin{array}{c}12+3+14 \\
+4+16+2 \\
+13+1+5 \\
+2+2+4\end{array}$ & $\begin{array}{c}12+3+14 \\
+4+16+2 \\
+13+1+5 \\
+2+2+4+9 \\
+10+12+8\end{array}$ \\
\hline
\end{tabular}

\begin{tabular}{|c|c|c|c|}
\hline 12 & 15 & 20 & 29 \\
\cline { 2 - 3 } 26 & 33 & 40 & 59 \\
\hline 42 & 51 & 60 & 91 \\
\hline 55 & 65 & 78 & 177 \\
\cline { 2 - 3 } & & &
\end{tabular}

Gambar 4 Perhitungan dengan integral image

Nilai fitur Haar $=\mid($ nilai piksel daerah hitam $)-($ nilai piksel daerah putih $) \mid$

$=|[78+15-(65+20)]-[65+12-(55+15)]|$

$=|8-7|$

$=1$

Selanjutnya adalah menghitung nilai piksel dari masing-masing daerah gelap dan terang pada area Haar template. Dari perhitungan di atas, pengurangan piksel daerah gelap dan terang akan didapatkan nilai fitur Haar sebesar 1. Nilai fitur Haar sebesar 1 inilah yang akan digunakan sebagai parameter klasifikasi objek yang terdeteksi sebagai ujung jari atau bukan. Jika nilai fitur berada di atas 1, maka citra dianggap terdapat ujung jari telunjuk. Sebaliknya jika nilai fitur di bawah 1, maka citra dianggap tidak terdapat ujung jari telunjuk. Sehingga nilai fitur Haar yang didapat akan dijadikan nilai ambang atau threshold. Perhitungan nilai fitur ini akan berlanjut dengan menggunakan fitur Haar lain dan di posisi yang berbeda pada citra yang dilakukan pelatihan. 
Setelah mendapatkan nilai fitur Haar, dilakukan langkah ketiga yaitu, melatih classifier berdasarkan berbagai nilai fitur Haar dengan menggunakan algoritma machine learning yang disebut Adaptive Boost atau AdaBoost. Pada classifier di dalamnya terdapat weak classifier yang terdiri dari nilai fitur, posisi dan, ukuran Haar tempalate yang dilatih pada citra. Untuk mendapatkan classifier yang kuat dilakukan metode pengklasifikasian bertingkat, dimana input dari setiap tingkatan merupakan output dari tingkatan sebelumnya. Semakin tinggi tingkat classifier, maka semakin banyak pula jumlah weak classifier yang ada. Hal ini mengakibatkan semakin sulitnya suatu sub-window untuk berhasil melewati tingkatan classifier tersebut, sehingga jumlah sub-window yang dieleminasi akan semakin banyak, dan jumlah sub-window yang berhasil lolos ke classifier tingkat selanjutnya akan semakin sedikit. Urutan dalam melatih classifier ditentukan oleh bobot nilai fitur yang diberikan AdaBoost. Nilai fitur dengan bobot paling besar diletakkan pada proses classifier yang pertama kali yang bertujuan untuk menghapus daerah citra yang bukan ujung jari telunjuk secepat mungkin. Untuk tingkatan classifer yang berikutnya diberikan nilai fitur dengan bobot yang lebih kecil dari tingkat classifier yang pertama. Begitu juga dengan nilai bobot fitur untuk tingkatan classifier yang berikutnya [4]. Hasil dari melatih classifier ini bertujuan untuk mendapatkan suatu keputusan apakah di dalam citra terdapat ujung jari telunjuk yang diinginkan atau tidak. Gambar 5 menunjukkan alur kerja dari klasifikasi bertingkat untuk melatih classifier.

Agar proses pengenalan ujung jari bisa diterapkan pada aplikasi web melalui tahap image processing, maka nilai fitur dan classifier yang telah dilatih melalui pengklasifikasian bertingkat akan disimpan dalam bentuk database pengenalan objek ujung jari telunjuk.

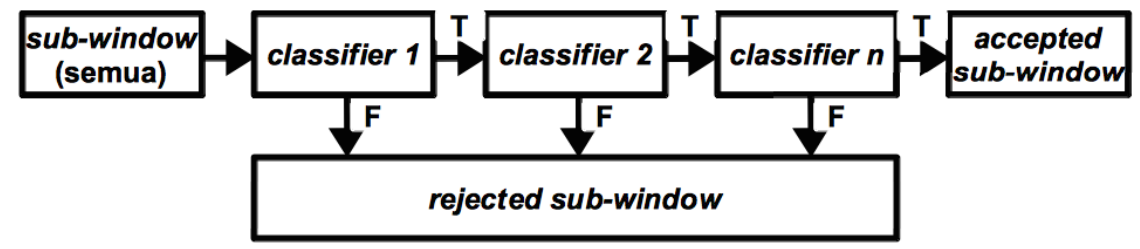

Gambar 5 Alur kerja klasifikasi bertingkat untuk melatih classifier

\subsubsection{Mengakses Webcam dengan Browser}

Proses inialisasi ini akan dilakukan oleh browser yang memiliki fitur dukungan webcam API (Application Programming Interface). Dengan menggunakan HTML5 getUserMedia API yang berbasis pada pemrogaman JavaScript yang telah dicantumkan pada sebuah aplikasi web, maka API ini secara otomatis akan dapat mengakses webcam dan microphone pada notebook. Langkah selanjutnya adalah melakukan recording dan menampilkannya secara langsung di aplikasi web. Webcam yang digunakan pada penelitian ini melakukan capture citra dengan ukuran 640 x 480 piksel. Untuk menampilkan hasil capture dari webcam, digunakan teknik penggambaran tiap frame dengan HTML5 Canvas yang dilakukan setiap $200 \mathrm{~ms}$, sehingga frame yang telah digambarkan seolah-olah bergerak seperti video hasil recording dari webcam. Hasil penggambaran oleh HTML5 Canvas akan menghasilkan frame citra berbentuk data raw (blob).

\subsubsection{Pengiriman Frame Citra ke Server Localhost}

Hasil penggambaran tiap frame citra dengan HTML5 Canvas yang berbentuk data raw akan dikirimkan secara langsung ke server localhost. Frame hasil penggambaran dari HTML5 Canvas berbentuk data raw ini akan dirubah terlebih dahulu ke format image yaitu jpg. Setelah berhasil membuat image dengan format jpg, maka dilakukan proses pengiriman ke server localhost melalui koneksi WebSockets. Setelah sampai di server localhost, frame citra akan disimpan ke buffer yang bersifat sementara (temporary). 


\subsubsection{Deteksi Posisi Ujung Jari Telunjuk}

Untuk melakukan deteksi posisi ujung jari telunjuk pada tahap image processing ini, dibutuhkan database hasil dari pelatihan pengenalan ujung jari telunjuk pada tahap yang pertama. Setiap frame citra yang disimpan dalam buffer, akan dilakukan proses pendeteksian dengan menggunakan metode cascade classifier atau klasifikasi bertingkat seperti yang ditunjukkan prosesnya pada Gambar 5. Frame citra yang telah diambil dari buffer akan melewati tahap classifier pertama dengan inputan adalah seluruh sub-window pada frame citra. Semua sub-window pada frame citra yang telah berhasil melewati classifier pertama akan dilanjutkan ke tahap classifier kedua, kemudian sub-window yang juga berhasil melewati classifier kedua akan dilanjutkan ke tahap classifier ketiga, dan seterusnya. Apabila suatu subwindow berhasil melewati semua tingkatan classifier, maka sub-window tersebut dinyatakan sebagai ujung jari telunjuk. Sedangkan untuk sub-window yang gagal melewati suatu tingkat classifier akan langsung dieleminasi dan dinyatakan sebagai bukan ujung jari telunjuk.

Frame citra yang berhasil terdeteksi di dalamnya terdapat ujung jari telunjuk akan menghasilkan nilai koordinat awal dan panjang area dari ujung jari telunjuk. Untuk menentukan posisi ujung jari telunjuk, perlu dicari nilai titik tengah dari area ujung jari telunjuk yang terdeteksi seperti yang ditunjukkan pada Gambar 6.

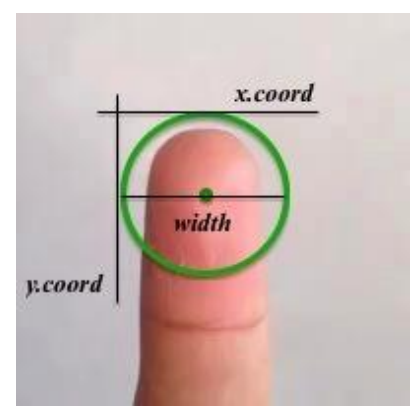

Gambar 6 Area pada ujung jari telunjuk yang terdeteksi

Untuk menghitung nilai titik tengah dari area ujung jari telunjuk yang terdeteksi digunakan persamaan (1), yaitu nilai koordinat awal pada tepi area (x.coord dan y.coord) kemudian ditambahkan dengan setengah nilai panjang area (width / height). Maka akan didapatkan nilai koordinat posisi ujung jari telunjuk yang sebenarnya pada sumbu $x$ (horizontal) maupun sumbu $y$ (vertikal). Nilai koordinat piksel yang dihasilkan berkisar antara $0-640$ piksel untuk koordinat horizontal dan $0-480$ piksel untuk koordinat vertikal sesuai dengan ukuran frame citra hasil capture dari webcam yaitu $640 \times 480$ piksel.

$$
\begin{aligned}
& x \text { Axis }=x . \text { coord }+ \text { width } / 2 \\
& y \text { Axis }=y \text { coord }+ \text { height } / 2
\end{aligned}
$$

Dengan didapatkannya kedua nilai koordinat posisi objek di atas, maka nilai tersebut yang akan dijadikan acuan untuk menentukan posisi masing-masing tombol pada keyboard virtual. Untuk memudahkan pembacaan nilai koordinat posisi objek pada aplikasi web di client, maka nilai tersebut dirubah ke dalam format JSON yang mendukung bahasa pemrogaman JavaScript. Format yang disajikan adalah $\{\mathrm{x}=\mathrm{xAxis}, \mathrm{y}=\mathrm{yAxis}\}$.

\subsubsection{Object Drawing}

Proses tahap kedua di bagian image processing ini akan melakukan penggambaran pada ujung jari yang terdeteksi (object drawing). Penggambaran dilakukan dengan mengacu pada nilai titik tengah dan panjang area pada ujung jari yang terdeteksi. Proses penggambaran yang dilakukan adalah dengan menggambarkan bentuk lingkaran berwarna hijau pada ujung jari telunjuk yang terdeteksi.

Apabila suatu frame citra tidak berhasil mendeteksi ujung jari telunjuk, maka proses object drawing tidak akan dilakukan. Sehingga frame citra yang berhasil maupun tidak berhasil

IJEIS Vol. 5, No. 2, October 2015 : $111-122$ 
dilakukan penggambaran akan disimpan di kembali dalam buffer yang bersifat sementara/temporary.

\subsubsection{Menampilkan Karakter dan Merancang Antarmuka Aplikasi Web}

Untuk menampilkan karakter dari tombol-tombol keyboard virtual digunakan pemrograman JavaScript. Karakter yang akan ditampilkan adalah huruf dari A - Z dan angka dari 0 - 9. Setiap karakter yang ditampilkan akan ditentukan terlebih dahulu nilai koordinat posisinya. Untuk menampilkan karakter yang dipilih oleh ujung jari telunjuk, maka nilai koordinat posisi ujung jari telunjuk yang telah terdeteksi dalam format JSON akan dibaca oleh JavaScript. Karakter akan tampil ketika koordinat posisi ujung jari telunjuk mempunyai nilai yang sama dengan range nilai koordinat yang telah ditentukan pada masing-masing karakter keyboard virtual. Misal, koordinat tombol karakter Q pada keyboard virtual diatur koordinat posisinya antara $50 \leq x \leq 86$ dan $93 \leq y \leq 129$. Ketika koordinat posisi ujung jari telunjuk yang terdeteksi bernilai $\mathrm{x}=70$ dan $\mathrm{y}=100$, maka karakter $\mathrm{Q}$ akan tampil pada form.

\subsubsection{Implementasi Sistem}

Implementasi sistem ini menggunakan perangkat keras dan perangkat lunak sebagai berikut:

1. MacBook Pro MB990, 2.26 Ghz Intel Core 2 Duo, 4GB 1067 Mhz DDR3 RAM

2. $\quad$ Sistem Operasi Mac OS X 10.8.5 Mountain Lion

3. iSight (webcam) pada MacBook Pro

4. OpenCV v2.5

5. Node.js v0.10.20

6. Browser Google Chrome v31.0

7. jQuery v2.0.0

Untuk melakukan implementasi sistem pada penelitian ini adalah dengan menjalankan server localhost melalui Terminal. Setelah sistem server localhost berjalan, buka browser Google Chrome dan ketikkan alamat URL http://localhost:8080/. Ketika mengakses alamat tersebut, browser akan melakukan inialisasi dan mengaktifkan webcam. Webcam melakukan capture citra dan menampilkannya di aplikasi web, posisikan ujung jari telunjuk mengarah ke arah webcam sehingga ujung jari telunjuk ter-capture dan langsung terlihat di aplikasi web. Selang seper sekian detik, ujung jari akan terdeteksi dengan ditandai lingkaran berwarna hijau. Arahkan ujung jari telunjuk ke tombol karakter pada keyboard virtual yang diinginkan. Maka akan terlihat efek menekan tombol keyboard virtual dan selang beberapa detik karakter yang dipilih akan ditampilkan di form pada aplikasi web. Hasil implementasi sistem berupa antarmuka pada aplikasi web ditunjukkan pada Gambar 7.

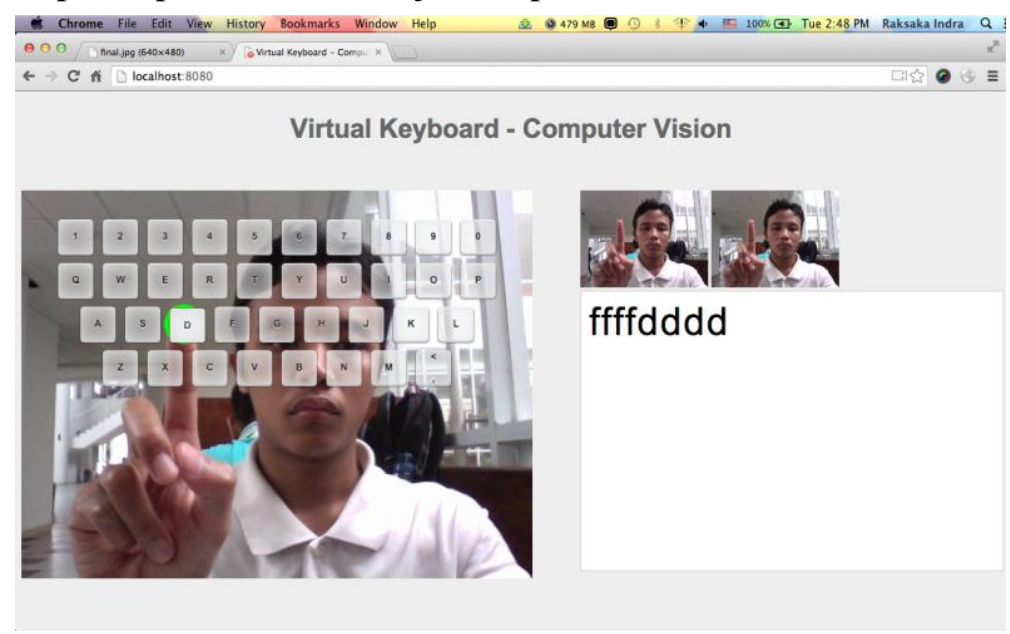

Gambar 7 Hasil implementasi sistem pada aplikasi web di Google Chrome 


\section{HASIL DAN PEMBAHASAN}

\subsection{Pengujian Pengaruh Intensitas Cahaya dalam Ruangan}

Pengujian pengaruh intensitas cahaya digunakan di dalam ruangan dengan 4 kondis yang berbeda. Untuk mengukur besarnya intensitas cahaya, penulis menggunakan light meter dengan merk Krisbow ${ }^{\circledR}$ seri KW06-288. Light meter berfungsi untuk mengukur tingi rendahnya intensitas cahaya dengan satuan lux yang ada di sekitar ruangan pengujian.

Tabel 1 Hasil pengujian pengaruh intensitas cahaya dalam ruangan

\begin{tabular}{|c|l|c|c|c|}
\hline No. & \multicolumn{1}{|c|}{ Kondisi Ruangan } & $\begin{array}{c}\text { Intensitas } \\
\text { Cahaya }(l u x)\end{array}$ & $\begin{array}{c}\text { Jumlah } \\
\text { Percobaan }\end{array}$ & Keterangan \\
\hline 1. & Gelap & $5-10$ & 10 & 0 terdeteksi, 10 error \\
\hline 2. & Cahaya lampu sedang & $30-50$ & 10 & 9 terdeteksi, 1 error \\
\hline 3. & Cahaya matahari & $60-80$ & 10 & 10 terdeteksi, 0 error \\
\hline 4. & Cahaya lampu terang & $100-125$ & 10 & 10 terdeteksi, 0 error \\
\hline
\end{tabular}

Berdasarkan hasil pengujian yang telah dilakukan sebanyak 10 kali percobaan, dapat dilihat pada Tabel 1 bahwa sistem dapat mendeteksi ujung jari telunjuk dengan baik pada 3 ruangan, yaitu ruangan dengan cahaya lampu sedang, lampu terang, dan terkena cahaya matahari. Pada ruangan dengan lampu terang dan ruangan yang terkena cahaya matahari, sistem berhasil mendeteksi ujung jari telunjuk sebanyak 10 kali. Sedangkan pada ruangan dengan cahaya lampu sedang, sistem berhasil mendeteksi ujung jari telunjuk sebanyak 9 kali. Dengan demikian, salah satu faktor utama yang mempengaruhi pendeteksian objek adalah intensitas cahaya pada ruang uji, semakin gelap kondisi ruangan, maka semakin kecil nilai intensitas cahayanya sehingga sistem akan semakin sulit untuk mendeteksi objek ujung jari telunjuk.

\subsection{Pengujian Jarak Ujung Jari Telunjuk Terhadap Webcam}

Pengujian jarak objek ujung jari telunjuk terhadap webcam dilakukan untuk mengetahui jarak maksimal dan minimal yang dapat dideteksi oleh sistem. Pengujian ini dilakukan dengan cara melakukan variasi jarak horizontal antara webcam dengan ujung jari telunjuk pada ruangan terang dengan intensitas cahaya antara $100-125$ lux.

Tabel 2 Hasil pengujian jarak ujung jari telunjuk terhadap webcam

\begin{tabular}{|c|c|c|c|}
\hline No. & Jarak $(\mathrm{cm})$ & Jumlah Percobaan & Keterangan \\
\hline 1. & 10 & 10 & 10 terdeteksi, 0 error \\
\hline 2. & 15 & 10 & 10 terdeteksi, 0 error \\
\hline 3. & 20 & 10 & 10 terdeteksi, 0 error \\
\hline 4. & 25 & 10 & 9 terdeteksi, error \\
\hline 5. & 30 & 10 & 10 terdeteksi, 0 error \\
\hline 6. & 35 & 10 & 9 terdeteksi, error \\
\hline 7. & 40 & 10 & 8 terdeteksi, error \\
\hline 8. & 45 & 10 & 6 terdeteksi, 4 error \\
\hline 9. & 50 & 10 & 6 terdeteksi, 4 error \\
\hline 10. & 55 & 10 & 3 terdeteksi, 7 error \\
\hline 11. & 60 & 10 & 1 terdeteksi, error \\
\hline 12. & 65 & 10 & 0 terdeteksi, 10 error \\
\hline 13. & $>65$ & 10 & 0 terdeteksi, 10 error \\
\hline
\end{tabular}


Dari hasil pengujian yang dilakukan sebanyak 10 kali percobaan, seperti yang terlihat pada Tabel 2 bahwa jarak yang dapat dideteksi oleh sistem melalui webcam terletak pada jarak 5 hingga $60 \mathrm{~cm}$. Pada jarak $10-50 \mathrm{~cm}$ menghasilkan objek yang paling banyak terdeteksi, sedangkan pada jarak lebih dari $50 \mathrm{~cm}$ objek sudah sulit terdeteksi oleh sistem melalui webcam. Semakin jauh jarak objek terhadap webcam, maka semakin kecil objek sehingga sistem sulit untuk melakukan pendeteksian. Untuk jarak yang paling optimal adalah antara $20-35 \mathrm{~cm}$, karena pada jarak tersebut ukuran ujung jari telunjuk yang terdeteksi sesuai dengan ukuran tombol pada keyboard virtual. Sedangkan pada jarak kurang dari $20 \mathrm{~cm}$, ukuran ujung jari yang terdeteksi terlalu besar dikarenakan semakin dekat dengan webcam. Akibatnya dua tombol keyboard virtual akan tertekan secara bersamaan.

\subsection{Pengujian dengan Variasi Latar Belakang/Background Ruangan}

Latar belakang atau background adalah salah satu hal yang dapat mempengaruhi pemrosesan pengolaha citra. Oleh karena itu, perlu dilakukan pengujian sistem dengan variasi latar belakang di dalam ruangan.

Tabel 3 Hasil dengan pengujian variasi latar belakang ruangan

\begin{tabular}{|c|l|c|c|}
\hline No. & \multicolumn{1}{|c|}{ Jenis Background Ruangan } & Jumlah Percobaan & Keterangan \\
\hline 1. & Putih dan polos & 10 & 10 terdeteksi, 0 error \\
\hline 2. & Coklat dan bercorak & 10 & 6 terdeteksi, 4 error \\
\hline 3. & Ruangan I & 10 & 9 terdeteksi, 1 error \\
\hline 4. & Ruangan II & 10 & 8 terdeteksi, 2 error \\
\hline
\end{tabular}

Dari hasil pengujian yang dilakukan sebanyak 10 kali percobaan, seperti yang ditunjukkan oleh Tabel 3 bahwa sistem dapat mendeteksi ujung jari dengan baik pada ruangan dengan background berwarna putih dan polos, terbukti dengan hasil percobaan yang berhasil sebanyak 10 kali. Hasil pengujian dengan latar belakang ruangan yang berwarna putih polos ditunjukkan pada Gambar 8 (a).

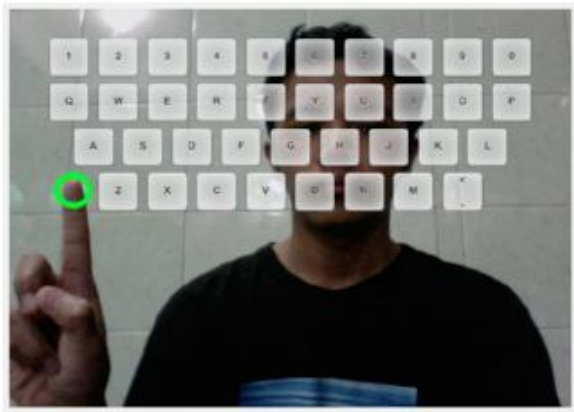

(a)

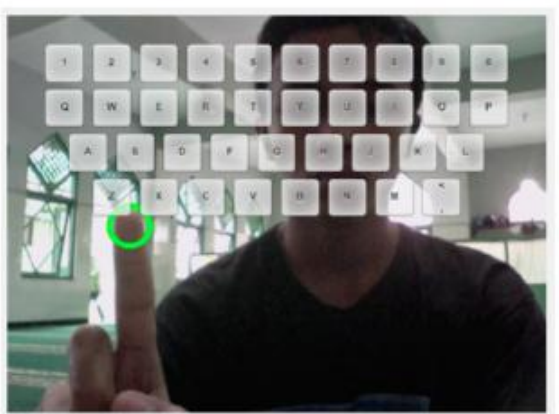

(c)

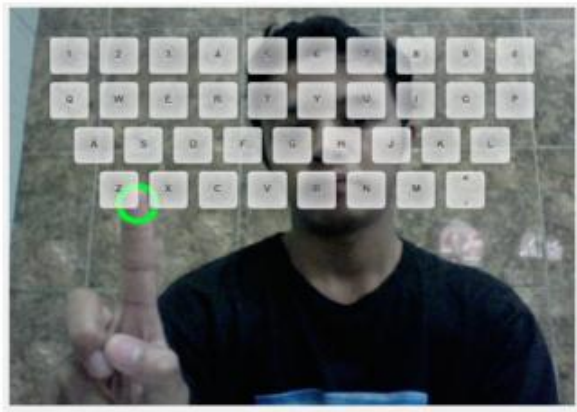

(b)

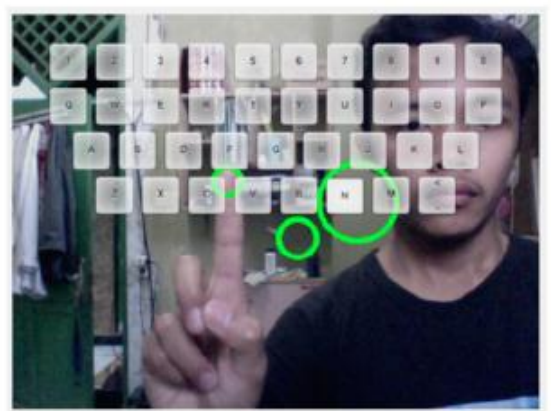

(d)

Gambar 8 (a) Pengujian pada latar belakang putih polos (b) Pengujian pada latar belakang coklat bercorak (c) Pengujian pada ruangan dengan sedikit perabot (d) Pengujian pada ruangan dengan banyak perabot 
Pada ruangan berlatar belakang berwarna coklat dan bercorak, sistem sedikit mengalami kesulitan dalam mendeteksi ujung jari telunjuk, terbukti hanya 6 kali yang berhasil terdeteksi. Hal ini dikarenakan warna coklat pada latar belakang memiliki warna yang hampir sama dengan warna kulit pada ujung jari telunjuk. Sistem mengalami kesulitan membedakan latar belakang dengan ujung jari dikarenakan nilai fitur yang dihasilkan antara daerah latar belakang dan objek di bawah nilai ambang (threshold). Sedangkan agar berhasil mendeteksi objek yang diinginkan, nilai fitur harus di atas nilai ambang (threshold). Hasil pengujian dengan latar belakang ruangan yang berwarna coklat dan bercorak ditunjukkan pada Gambar 8 (b).

Pada ruangan dengan latar belakang yang memiliki sedikit perabot, sistem dapat mendeteksi ujung jari telunjuk dengan baik, terbukti dengan 9 kali berhasil mendeteksi ujung jari di dalam percobaan. Hasil pengujian dengan latar belakang ruangan yang memiliki sedikit perabot ditunjukkan pada Gambar 8 (c).

Sedangkan pada ruangan dengan latar belakang yang memiliki banyak perabot, sistem juga masih dapat mendeteksi ujung jari telunjuk, terbukti berhasil melakukan pendeteksian sebanyak 8 kali. Namun, seperti yang ditunjukkan hasil pengujian pada Gambar 8 (d), terjadi kesalahan pada sistem dalam melakukan pendeteksian. Sistem juga mendeteksi benda-benda lain dengan ditandai adanya lingkaran berwarna hijau pada frame. Hal ini disebabkan bendabenda tersebut memiliki bentuk yang hampir sama dengan bentuk ujung jari telunjuk. Sehingga sistem menganggapnya sebagai ujung jari telunjuk.

Sehingga sistem akan mendeteksi ujung jari telunjuk dengan baik pada latar belakang yang berwarna putih polos atau di dalam ruangan dengan sedikit perabot di dalamnya. Sedangkan pada latar belakang berwarna coklat dan bercorak, sistem mengalami kesulitan mengenali ujung jari telunjuk dan terjadi kesalahan dalam mendeteksi objek selain ujung jari telunjuk.

\subsection{Pengujian Ketepatan dan Waktu Respon dalam Menampilkan Karakter Keyboard Virtual}

Perlu dilakukan pengujian ketepatan dalam menampilkan karakter untuk mengetahui tingkat keakuratan kinerja yang diberikan sistem melalui keyboard virtual sebagai antarmuka. Pengujian ini dilakukan dengan menuliskan susunan kata yang diinginkan dengan menggunakan keyboard virtual. Susuanan kata yang akan ditampilkan adalah "VIRTUAL KEYBOARD". Pengujian ini masih dilakukan pada ruangan dengan latar belakang putih polos dan dengan jarak ujung jari terhadap webcam $20-35 \mathrm{~cm}$.

Tabel 4 Hasil pengujian ketepatan dalam menampilkan karakter keyboard virtual

\begin{tabular}{|c|c|c|c|c|}
\hline No. & $\begin{array}{c}\text { Percobaan } \\
\text { ke- }\end{array}$ & $\begin{array}{c}\text { Karakter/Kata } \\
\text { yang Tampil }\end{array}$ & $\begin{array}{c}\text { JumlahError } \\
\text { Karakter }\end{array}$ & $\begin{array}{l}\text { Waktu respon } \\
\text { (menit) }\end{array}$ \\
\hline 1. & 1 & VIRTUAL KEJYYMBOARVD & 3 & $4: 13.89$ \\
\hline 2. & 2 & VITRTIUAL K $\underline{G E Y B O A} \underline{N} R D$ & 4 & 4:28.32 \\
\hline 3. & 3 & VPIRGTUAL KEYBOARD & 2 & $2: 50.46$ \\
\hline 4. & 4 & VITRNTUAL KTEEUYBOARD & 4 & $3: 13.87$ \\
\hline 5. & 5 & VIRTUZZAL KEYBJOARD & 2 & $2: 37.65$ \\
\hline
\end{tabular}

Dari hasil percobaan yang telah dilakukan sebanyak 5 kali dalam menampilkan susunan kata "VIRTUAL KEYBOARD", seperti yang ditunjukkan pada Tabel 4 bahwa keyboard vitual masih sering melakukan kesalahan (error) dalam menampilkan karakter yang tidak diinginkan dengan rata-rata error yang terjadi adalah 3 karakter. Kesalahan menampilkan karakter tersebut bisa disebabkan jarak antar tombol karakter keyboard virtual yang terlalu sempit sehingga salah dalam menujuk karakter, atau bisa juga disebabkan sistem mendeteksi objek selain ujung jari telunjuk. Kesalahan dalam pendeteksian objek selain ujung jari telunjuk dapat terlihat pada Gambar 9 dimana terdapat 2 lingkaran berwarna hijau yang terdeteksi selain ujung jari telunjuk, yaitu pada ruas tulang bagian luar jari tengah dan tulang pipi. 


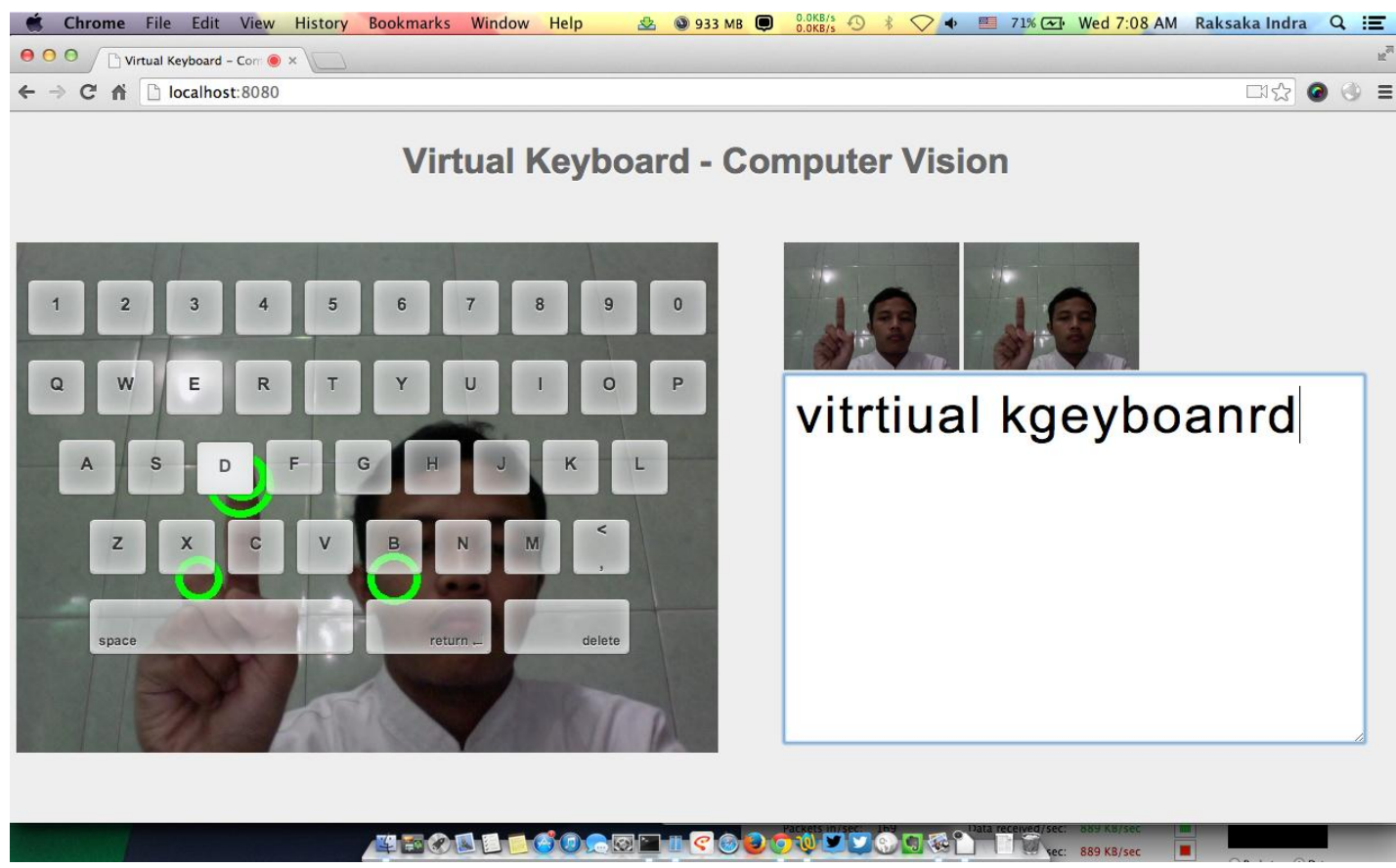

Gambar 9 Kesalahan pendeteksian selain ujung jari telunjuk pada pengujian ketepatan dalam menampilkan karakter keyboard virtual

Dari pengujian ini menujukkan keyboard virtual dalam aplikasi web ini belum bisa dijadikan sebagai antarmuka dikarenakan masih sulit digunakan dan tidak mendatangkan kemudahan bagi pengguna dalam berinteraksi, yang meliputi masih seringnya terjadi kesalahan menampilkan karakter yang tidak diinginkan dan waktu respon yang cukup lama dalam menuliskan susunan kata "VIRTUAL KEYBOARD" dengan rata-rata 3 menit 28,838 detik.

\section{KESIMPULAN}

berikut:

Dari penelitian yang telah dilakukan, dapat diambil beberapa kesimpulan sebagai

1. Metode yang digunakan untuk mengenali ujung jari telunjuk dengan menggunakan metode Haar Cascade Classifier sudah berjalan dengan cukup baik.

2. Jarak optimal secara horizontal antara ujung jari telunjuk dan webcam adalah $20-35 \mathrm{~cm}$.

3. Sistem mampu mengenali ujung jari telunjuk pada ruangan berlatar belakang warna putih polos dan ruangan dengan sedikit perabot di dalamnya. Sistem mengalami kesulitan mengenali ujung jari telunjuk pada ruangan berlatar belakang yang bercorak. Sedangkan pada ruangan dengan banyak perabot di dalamnya, sistem mengalami kesalahan berupa mendeteksi objek selain ujung jari telunjuk.

4. Waktu respon yang dibutuhkan untuk menampilkan susunan karakter "VIRTUAL KEYBOARD" pada keyboard virtual terhitung cukup lama dan kurang baik, dengan ratarata 3 menit 28,838 detik.

5. Keyboard virtual pada sistem ini belum mampu dijadikan sebagai antarmuka pada aplikasi web, dikarenakan masih sulit digunakan dalam mengarahkan ujung jari telunjuk ke tombol karakter yang diinginkan sehingga tidak mendatangkan kemudahan bagi pengguna dalam berinteraksi, serta masih terdapat error dalam menampilkan susunan kata/karakter pada keyboard virtual. 


\section{SARAN}

berikut:

Beberapa saran dari penulis untuk pengembangan sistem lebih lanjut adalah sebagai

1. Sebaiknya sistem ini dikembangkan agar dapat berjalan di cloud server, sehingga sistem dapat diakses dan digunakan oleh banyak orang dengan menggunakan browser.

2. Perlu diujikan pada berbagai browser yang telah beredar luas dan dapat digunakan juga pada tablet atau smartphone.

3. Dikarenakan antarmuka berupa keyboard virtual masih kurang efektif ketika diimplementasikan, maka perlu dikembangkan antarmuka berupa interaksi menggambar atau dapat mengendalikan game menggunakan ujung jari telunjuk pada aplikasi web.

\section{DAFTAR PUSTAKA}

[1] Ramadijanti, N., Setiawardhana, dan Alhaqqi, R.M., 2010, Tracking Jari dengan Haar Cascade dan Filter Kalman pada Virtual Keyboard, Invotek, No.1, Vol.3, 1-9.

[2] Wijewantha, N.S., 2003, VistaKey: A Keyboard Without A Keyboard - A Type Of Virtual Keyboard, Tesis, Department of Computing Informatics Institute of Technology, Wellawatta, Sri Lanka.

[3] Santoso, H. dan Harjoko, A., 2013, Haar Cascade Classifier dan Algoritma AdaBoost untuk Deteksi Banyak Wajah dalam Ruang Kelas, Jurnal Teknologi, No.2, Vol.6, 108-115.

[4]Putro, M.D., Adji, T.B., dan Winduratna, B., 2012, Sistem Deteksi Wajah dengan Menggunakan Metode Viola-Jones, Seminar Nasional "Science, Engineering and Technology", Yogyakarta. 